\title{
LIVELIHOOD REALISM: A REVIEW ON CLOSED TEA GARDENS OF DOOARS, WEST BENGAL
}

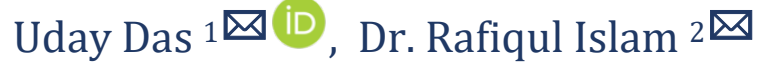 \\ ${ }^{1} \mathrm{PhD}$ Research Scholar (UGC Junior Research Fellow), Visva-Bharati, Shantiniketan, India \\ ${ }^{2}$ Associate Professor, Department of Lifelong Learning \& Extension, Rural Extension Center \\ Visva-Bharati, Shanti Niketan, India
}

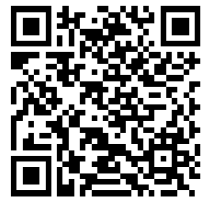

DOI: https://doi.org/10.29121/granthaalayah.v9.i2.2021.3355

Article Type: Research Article

Article Citation: Uday Das, and Dr. Rafiqul Islam. (2021). LIVELIHOOD REALISM: A REVIEW ON CLOSED TEA GARDENS OF DOOARS, WEST BENGAL. International Journal of Research -GRANTHAALAYAH, 9(2), 72-80.

https://doi.org/10.29121/granthaa layah.v9.i2.2021.3355

Received Date: 01 February 2021

Accepted Date: 23 February 2021

Keywords:

Closed Tea Garden

Dooars

Livelihood

\begin{abstract}
The paper is an attempt to understanding the ongoing livelihood realities in closed/ abandoned tea garden of Bengal-Dooars (Jalpaiguri and Alipurduar). The region produced large scale good qualities tea in more than 150 organised tea estates. Tea industry of North Bengal has been trashily affected by global economic quandary and local constraints. Many tea estates failed to manage the shock; the management closed many gardens. The garden closure and work shutdown have been produced a livelihood disaster. A school drop-out, child trafficking, Child labour mobility, rally of hunger and starvation death and extreme poverty is the ongoing livelihood phenomena in labour colonies of closed tea gardens. The present paper has discussed the particulars (housing, drinking water, medical facilities, education, liabilities etc.) of five closed gardens by using the data from TG Survey Final Report, Labour Commissionerate, Govt. of West Bengal and Tea Board of India.
\end{abstract}

\section{INTRODUCTION}

Export-oriented, labour intensive Indian tea industry had more than 180 years old own history. Charles Alexender Bruce (1797-1871) discovered tea bush in upper Assam in India. After his finding, about 1839 commercial tea cultivation started in colonial India by British planters. More than one million people directly employed, and three million indirectly engaged in the tea industry (Tea Board of India). Overall, 80 per cent of the tea labour are women, and they belong to Adivasi and Dalit communities. This backward (socially, economically and politically) tea labours are still sustained generation after generation with harsh livelihood condition (S Gothoskar 2012). In today price hike situation, tea labours working with a low wage and they are unable to effort the basic needs of their livelihood (P Kurmi 2014). The high school drop-out, inadequate medical facilities, unhygienic environment and the low wage rate is the principal problem of their life (Saikia et al. 2013). Truly they are hard worker and health is not the first preference for them. Still, their demands limited to the food and shelter (Roy et al. 2013).

Colonial planters central focus was continuous exploitation and surplus extraction. Cachar Plantation Enquiry Committee explains, Colonial planters shucking final drop of benefit, selling this exhausted property to Indian owners. "Economic deterioration and sickness of the tea industry had begun in the colonial time; it was accelerated under the ownership of Indian proprietors whose motive is not only to manufacture of tea but in the speculative

(C) 2021 The Author(s). This is an open access article distributed under the terms of the Creative Commons Attribution License, which permits unrestricted use, distribution, and reproduction in any medium, provided the original author and source are credited. 
Livelihood Realism: A Review on Closed Tea Gardens of Dooars, West Bengal

value of land" (U Thakur 1995). Regarding "sickness" of tea garden, National Council of Applied and Economic research explain, technical and economic factors of the tea industry. Tea Board India surveyed 115 tea garden and reported, natural Causes (cold climate, flood, drought, heavy rain and hail) are responsible for "Sickness" of tea industry in north-east India (U Thakur 1995).

Dooars situated in the northern part of West Bengal, geographically regions are the alluvial floodplain of a Himalayan foothill in north-eastern India. Jalpaiguri and Alipurduar districts consist of Bengal-Dooars. The region has been infiltrated by large scale commercial plantation agriculture. In 1876, the number of tea garden in north Bengal was only 13, which had increased 235 by 1901 (Xaxa V 1985). Now more than 450 gardens spread over the region and Jalpaiguri consists of 150 tea gardens. Large scale plantation industry gave rise indenture-labour movement, generally from central India (De Haan A 1995). These labours belong to tribal communities, Oraon and Munda consisted largest immigrants' tribal group. Tribal and Nepali labours are dependent on the plantation industry, but the frequent closure/sick syndrome of the industry has been produced a livelihood disaster.

Tea industry of North Bengal has been trashily affected by global economic quandary and local constraints. Many tea estates failed to manage the shock they witnessed production and benefit dilapidation (S Chakraborty 2013). The planters closed many gardens without prior notice and blocking labour payment, provident fund and gratuity. Thousands (nearly 20000) of tribal labours become jobless and died of starvation and malnutrition (N C Roy 2018). ActionAid (2005) reported 240 tea workers died in starvation and suicide within eleven months in just four tea gardens in West Bengal. The Dheklapara tea garden in Dooars has been closed since 2002, more than one thousand labour lost their work and reported 56 death due to starvation (A K Sen 2012). The administration, management and some trade union disapprove of starvation logic, but they confess about malnutrition (R Sen 2015). Extremely exploited tea labours are the victim of vote politics, they did not get their right and justice during the 34 years of the communist government and present government efforts failed to deliver adequate justice (A K Sen 2012). In 2005 a nutritional survey was conducted on tea workers of Dooars in West Bengal. The survey team collect data from six open, sick and closed tea garden. Four out of six tea garden identified as a starving group. All adult members can be labelled as a "starving community" or "at critical risk for mortality from starvation." The overall result is all surveyed garden showing alarming BMI rate. The study also found peoples are suffering from diarrhoea and vomiting, which influences to starvation related death. Vulnerable closed tea garden area converts to a potential field for traffickers. In North Bengal, trafficking incidence is higher among close and sick tea gardens than other tea gardens which did not face closure and sickness (S Chakraborty 2013). Human trafficking is the result of Poverty, hunger, economic exploitation, illiteracy, alcoholic father and unemployment (A T William 2008). Plantation Labour Act 1951 gradually eroded in closed gardens and thousands of labours livelihood is fatigued and exhausted. This paper is an attempt to shed some light on their crux livelihood reality and suggest some long-term strategy for sustainable livelihood.

\section{DATA AND METHODOLOGY}

The entire study was carried based on secondary data by using government reports, several publications and existing literature on closed/ sick tea industry. The abandoned garden was selected from 65th annual report 201819, Tea Board of India. The study covered five closed tea gardens based on available secondary information. Housing, drinking water, medical facilities, education and liabilities particulars of the abandoned tea estates were collected from TG Survey Final Report, Labour Commissionerate, Govt. of West Bengal.

\section{GLOOMY LIVELIHOOD PANORAMA OF CLOSED GARDENS}

Between 2002 and 2007, planter's authority had closed 17 gardens, the consequence is 1200 people have died due to hunger (Bhattacharya et al. 2019). Tea labourers live in an acute inadequacy of basic civic and social amenities. Consumption of impure water, improper toilet and sanitation worsens their exposure to communicable diseases and aggravate mortality conditions. Restrained accessibility to the health service and low nutrition intake dwindle their health status which in turn lowers their productivity, entrapping them into a vicious cycle (Gayathri \& Arjunan, 2018). Talwar (2005) reported a huge amount of liabilities of provident fund, wage, gratuity and other benefits, the total liabilities to the worker were more than 36 crores (only 17 months wage due). Ratna Sen (2015) noted the story of abandonment of closed tea gardens, workers are unable to manage their food and ration. The closed garden 
workers get rations (food grains) under AAY (Antodaya Anna Yojana) and monthly 500 hundred Rs. Through FAWLOI scheme. Many have migrated as construction labour and some tea workers collect stones from the river bed. MGNREGA has introduced but payments are delayed. PBKMS and IUF (2005) conducted a study on closed and reopened tea gardens of Dooars, through this long period of closure many labours have lost their family members to disease and malnutrition; the procession of deaths continuing due to poverty and hunger. Government intervention is still inadequate to assure them a rational income for livelihood.

Along with the economic crisis, much other hardship facing women and children. Child labour migration and missing is a serious problem, every year 8 to 10 children missing out of 100 children from closed and sick tea garden (B Ghosh 2014). Many studies noted a strong link between the story of missing and child trafficking (S Chakraborty 2013; B Ghosh 2014). Frequent closure/lockout syndrome-induced livelihood disaster made them (vulnerable tribal labour families) physically and mentally unstable; this reason's children and women are getting easier to labour trafficking than sex trafficking. A school drop-out, child trafficking, Child labour mobility, girl's child trafficking for prostitution, a rally of hunger and starvation death and extreme poverty is the ongoing livelihood phenomena in labour colonies of closed tea gardens of Dooars and COVID-19-induced lockdown had added more calamities.

Table 1: list of closed tea gardens of Dooars

\begin{tabular}{|c|c|c|}
\hline Tea Estate & Date of Closure & Present Status \\
\hline Red Bank Tea Estate & March 2003 & Closed \\
\hline Surendranagar Tea Estate & March 2003 & Closed \\
\hline Kathalguri Tea Estate & July 2002 & Reopened \\
\hline Dheklapara Tea Estate & August 2002 & Closed \\
\hline Dharanipur Tea Estate & March 2003 & Closed \\
\hline Raipur Tea Estate & October 2003 & Reopened \\
\hline Kalchini Tea Estate & October 2003 & Reopened \\
\hline Rahimabad Tea Estate & April 2002 & Reopened \\
\hline Jogesh Chandra Tea Estate & April 2003 & Reopened \\
\hline Bundapani tea estate & July 2013 & Closed \\
\hline Madhu tea estate & September 2014 & Closed \\
\hline Mujnai Tea Estate & April 2004 & Reopened \\
\hline
\end{tabular}

Source: PBKMS \& IUF Survey, 2005; 65 th Annual Report 2018-19, Tea Board India

Table-1 shows the list of some closed/sick tea gardens of Dooars, which is badly affected by 90 s global economic shock. During the crisis period (2002-2004) these tea estates gave closure noticed and planters were disappeared without paying workers PF, gratuity and wages. Most of the gardens are more than a hundred years old; surpluslabour, old tea bush, high labour cost, declining yield rate and global competition-induced export deterioration are the major squeezed factors by management for garden closure. Few gardens had reopened by the great efforts of district administration and labour union, and six tea estates are still closed (Tea Board India). 




\section{PARTICULARS OF CLOSED TEA GARDENS}

Tea Board of India (51st Annual report 2004-05) reported a total of 118 tea garden were closed during the period of extreme crisis of tea industry (2000-2005). According to the 65th annual report (2018-19) of Tea Board of India, at present Jalpaiguri and Alipurduar (Bengal-Dooars) district has six closed tea gardens. The study covered five closed tea gardens based on available secondary information.

Centre for Education and Communication published a situation report of closed tea gardens in 2007. A working paper interestingly noted a peculiar syndrome of some closed tea gardens, the tea garden reopens during peak season and again closed during the lean period. This frequent and repeatedly closure and reopen nature of tea gardens are more dangerous for the surviving labour. Closed and abandoned gardens get various government benefits and subsidies; reopening denoted that government intervention (ration subsidy, financial assistance, work and others) put on hold (Talwar et al. 2005). 
Bundapani: The garden has 5390 total population and almost 50 per cent are belonging from Schedule tribe community. The management failed to operate the garden and declared closure from 13.07.2013, according to the annual report of Tea Board of India, the garden is still closed. The garden has 1215 permanent worker, they are badly affected. Many workers are unable to manage the proper mill for his children since garden closure.

Dharanipur: The garden comes under Nagrakata Block, Jalpaiguri district. Dharanipur tea garden was closed in 19.10.2013, due to garden closure, 357 permanent and 450 temporary labour lost their job. Many starvations and malnutrition death have occurred since the closure. Former tea pickers are now collecting stones from Diana and Dhumchi river bed. The garden was maintained by Redbank group but now Dharanipur, Bundapani and Redbank tea estates acquired by the government.

Redbank: The garden situated in Dhupguri Block, according to 2011 Jalpaiguri district statistical handbook 907 households and 4114 population is residing in the garden. Overall, 68 per cent populations are ST and 2323 persons are literates. The management closed the garden in 19.10.2013, more than eight hundred permanent and seven hundred temporary workers become jobless. Many workers migrated to neighbouring cities for work.

Surendranagar: The garden authority and management left the garden in 19.10.2013, a sea change has taken place since the closure. More than 300 permanent and 150 temporary labour lost their only source of income. The worker families facing a challenge of hunger and malnutrition and a catastrophe of livelihood.

Madhu: The tea estate situated in Kalchini Block in Alipurduar district. According to 2011 census, the garden has 1000 families with 4540 total population. Overall, 63 per cent of peoples are ST and the number of total workers is 1790 . The garden management notified garden closure in 23.09.2014, the closure declaration despoils the work of 947 permanent workers.

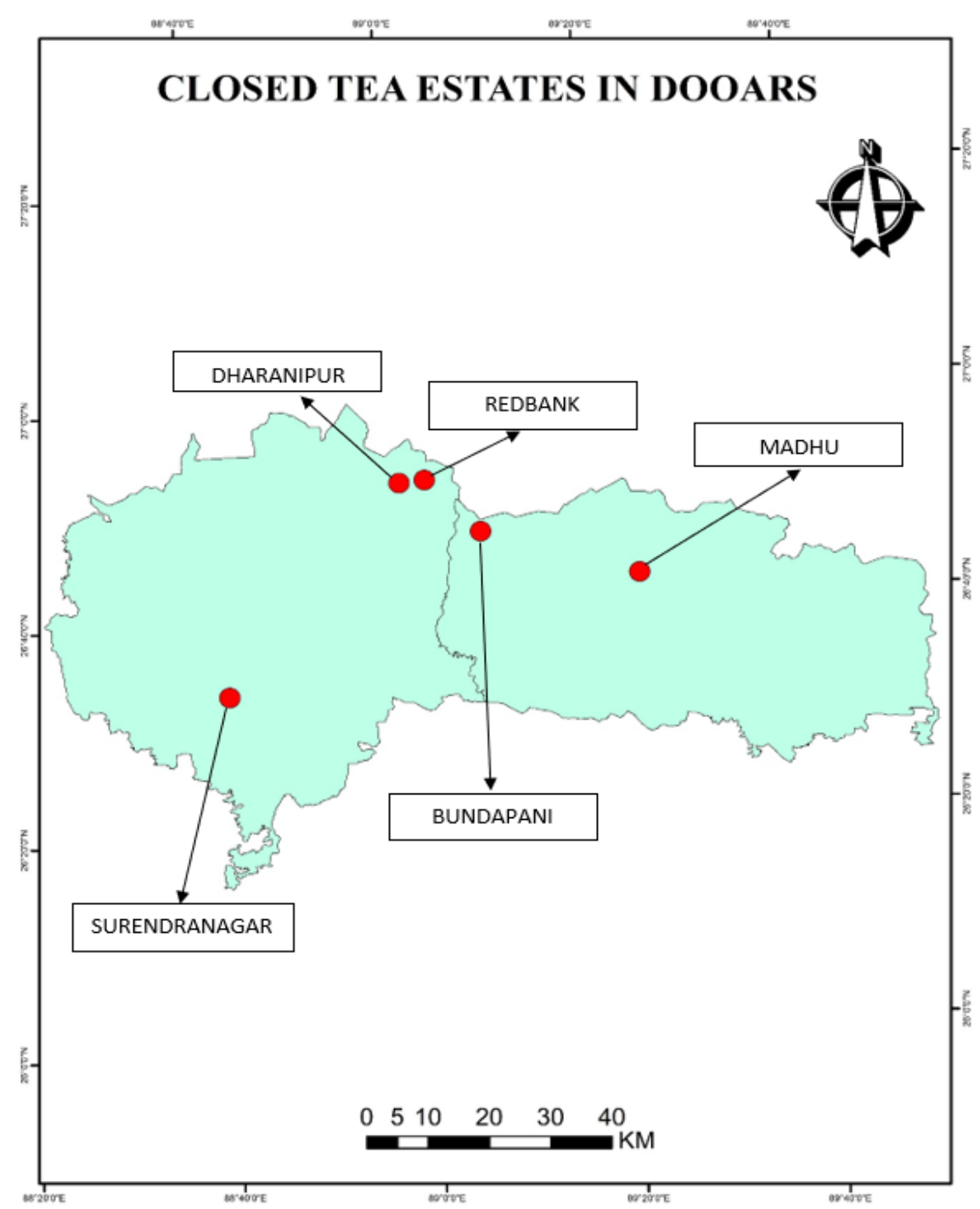


Livelihood Realism: A Review on Closed Tea Gardens of Dooars, West Bengal

Table 2: List of Selected Closed Tea Gardens

\begin{tabular}{|c|c|c|c|c|}
\hline Name of Tea Estates & Area Under Tea (HA) & Date of closure & Permanents & Temporary \\
\hline Bundapani & 530 & 13.07 .2013 & 1215 & 68 \\
\hline Dharanipur & 265 & 19.10 .2013 & 357 & 450 \\
\hline Redbank & 369 & 19.10 .2013 & 888 & 700 \\
\hline Surendranagar & 172 & 19.10 .2013 & 301 & 150 \\
\hline Madhu & 323 & 23.09 .2014 & 947 & - \\
\hline
\end{tabular}

Source: $65^{\text {th }}$ Annual Report 2018-19, Tea Board India

\section{AFTER CLOSURE LIVELIHOOD SITUATION OF THE GARDEN WORKERS}

Housing: Shelter is a basic necessity of human life and an indicator of wellbeing and standard of living. Table-3 shows the housing condition of the five closed tea gardens of Dooars. Bundapani an abandoned tea estate, a total of 707 workers houses are there and housing coverage is only 58 per cent. Overall, 43 per cent of houses are pucca, but the labour colony is not electrified. Dharanipur garden has the Most pathetic condition of housing (only 8 per cent), the total number of the house is only 30 and village (labour line) are still not electrified. Redbank and Madhu tea estates are electrified by cluster meter. Surendranagar and Redbank both gardens housing condition is very bad (only 10 per cent pucca house) and housing coverage is more than 60 per cent. Madhu tea estate's condition is quite better than other closed gardens. Surendranagar and Madhu gardens get 18 and 35 houses under Govt. scheme. Last four years Bundapani, Redbank, Dharanipur and Surendranagar tea garden gets zero expenditure for housing.

Table 3: Particulars of Housing of Selected Tea Garden

\begin{tabular}{|c|c|c|c|c|c|c|c|c|}
\hline \multirow[t]{2}{*}{ Tea Estate } & \multicolumn{4}{|c|}{ Houses } & \multirow{2}{*}{$\begin{array}{l}\text { Housing } \\
(\%)\end{array}$} & \multirow{2}{*}{$\begin{array}{l}\text { Electrified } \\
\text { House }\end{array}$} & \multirow{2}{*}{$\begin{array}{l}\text { Houses } \\
\text { under Govt. } \\
\text { Scheme }\end{array}$} & \multirow{2}{*}{$\begin{array}{c}\text { Total housing } \\
\text { expenditure (last } 4 \\
\text { years) }\end{array}$} \\
\hline & Pucca & $\begin{array}{l}\text { Semi- } \\
\text { pucca }\end{array}$ & Others & total & & & & \\
\hline Bundapani & 302 & 153 & 252 & 707 & 58 & 0 & 0 & 0 \\
\hline Dharanipur & 20 & 0 & 10 & 30 & 8 & 0 & 0 & 0 \\
\hline Redbank & 63 & 257 & 284 & 604 & 68 & All (CM) & 0 & 0 \\
\hline Surendranagar & 23 & 34 & 119 & 194 & 64 & 0 & 18 & 0 \\
\hline Madhu & 437 & 245 & 61 & 778 & 76 & All & 35 & 124882 \\
\hline
\end{tabular}

Source: TG Survey Final Report, Labour Commissionerate, Govt. of West Bengal

Drinking water: Fresh drinking water supply is a problem in the tea estates, many gardens worker still used drinking water from the river. Most of the tea garden drinking water supply is insufficient. In Dharanipur tea estates, Ring Well is the only source of drinking water and Ring Well is open, so more chance to contaminated by pollutants and pathogen. the garden has seven Ring Well, which is covered 261 houses. Bundapani, Redbank and Surendranagar garden has deep tube well. In Redbank garden, the company management provides pipeline water for 500 houses. Madhu tea estates population size is high and only one deep tube well covered 743 houses. According to Govt. of West Bengal labour Commissionerate tea survey report, all five closed gardens are not covered by "Sajal Dhara" scheme. All five closed gardens drinking water supply is not sufficient.

Table 4: Situation of Drinking Water Supply

\begin{tabular}{|c|c|c|c|c|c|c|c|c|c|c|c|}
\hline \multirow[t]{3}{*}{ Tea Estate } & \multirow{3}{*}{$\begin{array}{c}\text { Sourc } \\
\mathrm{e}\end{array}$} & \multicolumn{9}{|c|}{ Drinking water supply method } & \multirow{3}{*}{$\begin{array}{c}\text { Sajal } \\
\text { Dhar } \\
\text { a }\end{array}$} \\
\hline & & \multicolumn{2}{|c|}{ Deep-tube well } & \multicolumn{2}{|c|}{$\begin{array}{l}\text { Hand-tube } \\
\text { well }\end{array}$} & \multicolumn{2}{|c|}{ Ring well } & \multicolumn{2}{|c|}{ Kutcha well } & \multirow{2}{*}{$\begin{array}{c}\text { Pipelin } \\
\text { e } \\
\text { Houses } \\
\text { covere } \\
\text { d } \\
\end{array}$} & \\
\hline & & $\begin{array}{l}\text { Tota } \\
\text { l No. }\end{array}$ & $\begin{array}{c}\text { Houses } \\
\text { covere } \\
\text { d }\end{array}$ & $\begin{array}{l}\text { Tota } \\
\text { l No. }\end{array}$ & $\begin{array}{c}\text { Houses } \\
\text { covere } \\
\text { d }\end{array}$ & $\begin{array}{l}\text { Tota } \\
\text { l No. }\end{array}$ & $\begin{array}{c}\text { Houses } \\
\text { covere } \\
\text { d }\end{array}$ & $\begin{array}{l}\text { Tota } \\
\text { l No. }\end{array}$ & $\begin{array}{c}\text { Houses } \\
\text { covere } \\
\text { d }\end{array}$ & & \\
\hline Bundapani & $\begin{array}{l}\text { Deep } \\
\text { Tube } \\
\text { well } \\
\end{array}$ & 2 & 235 & 12 & 357 & 0 & 0 & 0 & 0 & 0 & NO \\
\hline
\end{tabular}


Uday Das, and Dr. Rafiqul Islam

\begin{tabular}{|c|c|c|c|c|c|c|c|c|c|c|c|}
\hline Dharanipur & $\begin{array}{c}\text { Ring } \\
\text { well }\end{array}$ & 0 & 0 & 0 & 0 & 7 & 261 & 0 & 0 & 0 & NO \\
\hline Redbank & $\begin{array}{l}\text { Deep } \\
\text { Tube } \\
\text { Well }\end{array}$ & 1 & 405 & 10 & 100 & & & & & 500 & NO \\
\hline $\begin{array}{c}\text { Surendranaga } \\
\text { r }\end{array}$ & $\begin{array}{l}\text { Deep } \\
\text { Tube } \\
\text { well }\end{array}$ & NA & NA & NA & NA & 0 & 0 & 0 & 0 & 0 & NA \\
\hline Madhu & $\begin{array}{l}\text { Deep } \\
\text { Tube } \\
\text { well, } \\
\text { Ring } \\
\text { well, } \\
\text { Hand } \\
\text { Tube } \\
\text { well }\end{array}$ \\
\hline
\end{tabular}

Source: TG Survey Final Report, Labour Commissionerate, Govt. of West Bengal

Hospital and Medical Facilities: Inadequate supply of clean drinking water, lack of safe sanitation, ignorance about proper hygiene due to low literacy and low standard of living make tea labours exposed to multiple Disease. The tea garden has hospitals for garden labour and the hospital environment is well decorated. But health care services are inadequate, and all patients have treated as an outdoor case; the same syringe and needle continuously used for injection throughout the day and doctor doesn't approve them for minor illness (fever, headache, cough and cold, digest problem), that's why they always ignore their minor ailment (Roy et al. 2013).

Table-5 shows hospital and medical services in five closed tea gardens. Every tea garden has one hospital or dispensary; only Surendranagar garden has no bed for patients. Bundapani and Surendranagar hospital/ dispensary is running without nurses. All gardens have approved medicine list except Dharanipur.

Table 5: Hospital and Medical services

\begin{tabular}{|c|c|c|c|c|c|}
\hline Tea Estate & $\begin{array}{c}\text { No of } \\
\text { Hospital/Dispensary }\end{array}$ & $\begin{array}{c}\text { No. of } \\
\text { Beds }\end{array}$ & $\begin{array}{c}\text { No. of } \\
\text { Nurses }\end{array}$ & $\begin{array}{c}\text { No. of } \\
\text { Midwife }\end{array}$ & $\begin{array}{c}\text { Approved medicine list } \\
\text { available or not }\end{array}$ \\
\hline Bundapani & 1 & 26 & 0 & 2 & Yes \\
\hline Dharanipur & 1 (dispensary) & 5 & 1 & 1 & NO \\
\hline Redbank & 1 & 19 & 1 & 0 & Yes \\
\hline Surendranagar & 1 (dispensary) & 0 & 0 & 1 & Yes \\
\hline Madhu & 1 & 17 & 3 & 1 & \\
\hline
\end{tabular}

Source: TG Survey Final Report, Labour Commissionerate, Govt. of West Bengal

Education and School: Education is the leading pillar for prosperous human civilization. It may help to improve individual and community social status, living standard and quality of life. Intellectual and civic society are possible through enhancing educational foothold and need-based learning. However, tea garden labours educational circumstance is not much improved yet. Still, they adjusted behind the proper rays of education. Holistic development and economic growth of tea labour community are possible through education (Kurmi 2014).

Table 6 shows information about schools of closed tea gardens. The school exists in every tea garden but the dropout rate is high among the abandoned garden. Management provides vehicles for school-going children, but Dharanipur and Madhu garden management did not provide any vehicles for school-going children. Only Bundapani garden has a school bus; Redbank and Surendranagar provide canter and truck for school-going children.

Table 6: Particulars of School Infrastructure

\begin{tabular}{|c|c|c|}
\hline Tea Estate & School exists or not & Vehicle for school going children \\
\hline Bundapani & Yes & School bus \\
\hline Dharanipur & Yes & NO \\
\hline
\end{tabular}


Livelihood Realism: A Review on Closed Tea Gardens of Dooars, West Bengal

\begin{tabular}{|c|c|c|}
\hline Redbank & Yes & Canter \\
\hline Surendranagar & Yes & Truck \\
\hline Madhu & Yes & NO \\
\hline
\end{tabular}

Source: TG Survey Final Report, Labour Commissionerate, Govt. of West Bengal

Payment dues: Table-7 shows the figure of provident fund, wages, arrear wage, ration and other benefits dues. The management disappeared and left the garden without paying labour dues. Dharanipur, Redbank, Surendranagar and Madhu tea estates have huge PF dues and every closed garden shows wages and ration due. Every garden reported huge liabilities to labour; Dharanipur had highest wages due and Surendranagar reported Rs. 2689977 as arrear wage due to worker. Wage and ration due create hunger and malnutrition syndrome among tea workers. The government providing rice through AAY and financial assistance (1500 Rs) under FAWLOI scheme. Tea workers livelihood is dependent on the garden but the closure phenomena make them vulnerable.

Table 7: Liabilities to Tea Workers

\begin{tabular}{|c|c|c|c|c|c|c|}
\hline \multirow[t]{2}{*}{ Tea Estate } & \multicolumn{2}{|c|}{ P.F Due } & \multirow{2}{*}{$\begin{array}{l}\text { Wages } \\
\text { Due }\end{array}$} & \multirow{2}{*}{$\begin{array}{l}\text { Ration } \\
\text { Due }\end{array}$} & \multirow{2}{*}{$\begin{array}{c}\text { Fire } \\
\text { wood/Umbrella/Chappal/Blanke } \\
\text { t etc. Due }\end{array}$} & \multirow{2}{*}{$\begin{array}{l}\text { Arrear } \\
\text { Wages } \\
\text { Due }\end{array}$} \\
\hline & $\begin{array}{c}\text { Workers } \\
\text { Contributio } \\
\mathrm{n}\end{array}$ & $\begin{array}{l}\text { Managemen } \\
\mathrm{t} \\
\text { Contribution }\end{array}$ & & & & \\
\hline Bundapani & 0 & 0 & Yes & Yes & YES & Nil \\
\hline Dharanipur & 8770342 & 3587495 & $\begin{array}{c}94805 \\
3\end{array}$ & Yes & Yes & 826481 \\
\hline Redbank & 1730975 & 1963863 & $\begin{array}{c}65946 \\
9\end{array}$ & Nil & Yes & Yes \\
\hline $\begin{array}{c}\text { Surendranaga } \\
\mathrm{r}\end{array}$ & 1568364 & 3840028 & $\begin{array}{c}19959 \\
3\end{array}$ & $\begin{array}{c}28559 \\
3\end{array}$ & Fire wood, Umbrella, Chappal due & $\begin{array}{c}268997 \\
7\end{array}$ \\
\hline Madhu & 6175831 & 22070802 & Yes & Yes & Yes & $\begin{array}{c}170000 \\
0\end{array}$ \\
\hline
\end{tabular}

Source: TG Survey Final Report, Labour Commissionerate, Govt. of West Bengal

\section{ALTERNATIVE LIVELIHOOD AND INCOME STRATEGY}

Alternative livelihood income sources are not adequate outside of the tea garden. Migration is one of the important strategies for workers of closed gardens. Various government schemes and assistance are available but most of the scheme's aim is to provide food security but livelihood security is more necessary than food security. Government intervention should include sustainable income generation through an alternative employment generation scheme. Closed tea garden areas have potential eco-tourism attractions; multicultural diversity would be another feather to developed garden-based eco-tourism. Dooars are a well-known international and domestic tourist destination for nature lovers; there need collaboration between Government-tourism department-OMC to develop garden-stay tourism infrastructure. That will generate an alternative source of income to overcome the situation of gloomy livelihood situation of closed gardens workers. Every tribal community have a rich culture of handicrafts, which is dilapidated now; financial assistance (Govt. scheme) and the tourism industry would help to rejuvenate their handicrafts, which will create another source of alternative livelihood. Collaboration (ManagementLabour- Govt.) and bona fides are needed to reopen the abandoned gardens.

\section{CONCLUSION}

The study has discussed the crux livelihood reality of the worker since the closure of the garden. Huge amounts of liabilities to workers, the management should be paid that dues. Plantation Labour Act of 1951 gradually eroded and Tea labourers live in an acute inadequacy of basic civic and social amenities. There needs a long-term reopening and sound operating plan to rejuvenate the industry. Trafficking incidence is higher among close and sick tea gardens; the administration has to take a strong initiative to tackle the situation of human trafficking. Sustainable income and long-run employment generation through Government intervention are necessary, which will ensure an 
Uday Das, and Dr. Rafiqul Islam

alternative source of livelihood. A revitalization movement is required for rejuvenation of the distressed tea industry.

\section{SOURCES OF FUNDING}

This research received no specific grant from any funding agency in the public, commercial, or not-for-profit sectors.

\section{CONFLICT OF INTEREST}

The author have declared that no competing interests exist.

\section{ACKNOWLEDGMENT}

None.

\section{REFERENCES}

[1] ActionAid, "Tea Break - A Crisis Brewing in India", UK, 2005

[2] Behind Closed and Abandoned Tea Gardens- Status Report of India (2007), www.cec-india.org

[3] Bhattacharya, A., Deb, R., Kapoor, C. (2019) Photo feature: Struggle and hope in the tea gardens of the Dooars. https://scroll.in/article/940717/photo-feature-struggle-and-hope-in-the-tea-gardens-of-the-dooars

[4] Biswas, S., Chokraborty, D., Berman, S., \& Berman, J. (2005). Nutritional Survey of Tea Workers on Closed, ReOpened, and Open Tea Plantations of the Dooars Region, West Bengal, India. Paschim Banga Khet MajoorSamity (West Bengal Agricultural Workers" Association), in association with the International Union of Foodworkers and the American Jewish World Service.

[5] Chakraborty, S. (2013). Tea, tragedy and child trafficking in the Terai Dooars. Economic and Political Weekly, 17-19.

[6] De Haan, A. (1995). Migration in eastern India: A segmented labour market. The Indian Economic \& Social History Review, 32(1), 51-93.

[7] Ghosh, B. (2014). Vulnerability, forced migration and trafficking in children and women: A field view from the plantation industry in West Bengal. Economic and Political Weekly, 58-65.

[8] GOTHOSKAR, S. (2012). This Chāy Is Bitter: Exploitative Relations in the Tea Industry. Economic and Political Weekly, 47(50), 33-40. Retrieved February 2, 2021, from http://www.jstor.org/stable/41720464

[9] Kurmi, P. (2014). Problem of Educational Attainment of Children, A case Study of the Tea Garden Labourer's Households in Derby Tea Estate. Research journal of language, literature and humanities, 1(4), 1-7.

[10] Roy, N. C., \& Biswas, D. (2018). Closed Tea Estates: A Case Study of the Dooars Region of West Bengal, India. Vision, 22(3), 329-334.

[11] Roy, S. K., Kar Chakraborty, S., \& Mozumdar, A. (2013). Health: Cognition and Threshold among the Oraon Tea Garden Labourers of Jalpaiguri District, West Bengal. Journal of Anthropology, 2013.

[12] Sen, A. K. (2012). Plight of Tea Garden Workers. Economic and Political Weekly, 47(6), 5-5.

[13] Sen, R. (2015). Tea Workers-Distressed in the Organized Industry in North Bengal. THE INDIAN JOURNAL OF INDUSTRIAL RELATIONS, 535-549.

[14] Saikia, S., Misra, S., \& Misra, B. (2013). Tea garden labours and their living conditions: a study on sarusarai tea garden of jorhat district of Assam.

[15] Talwar, A., Chakraborty, D., \& Biswas, S. (2005). Study on closed and re-opened tea gardens in North Bengal. Paschim Banga Khet Majoor Samity and International Union of Food, Agriculture, Hotel, Restaurant, Catering, Tobacco, Plantation and Allied Workers Association (IUF).

[16] Thakur, U. (1995). " Sick" Tea Plantations in Assam and Bengal. Labour, Capital and Society/Travail, capital et société, 44-66.

[17] Xaxa, V. (1985). Colonial capitalism and underdevelopment in North Bengal. Economic and Political Weekly, 1659-1665. 